\title{
ON-FARM ADAPTATION OF SOME OILSEED CROPS UNDER ACIDIC SOIL OF SYLHET REGION IN BANGLADESH
}

\author{
*M. I. Nazrul ${ }^{1}$ and M. Akkas Ali ${ }^{2}$ \\ ${ }^{1} \mathrm{PSO},{ }^{2} \mathrm{CSO} \&$ Head, OFRD, BARI, Bangladesh \\ *Corresponding Email: mi_nazrul@yahoo.com
}

(Received: 13 October, 2020, Accepted: 26 October, 2020)

Key words: Oilseed crops, adaptation, crop productivity, acidic soil

\begin{abstract}
Screening of improve varieties for new areas is necessary to address the soil and environment for improving crop production systems. In this context, six separate field trials were conducted at farmer's field in Sylhet areas for the two consecutive crop seasons during 2017-18 and 2018-19, respectively to evaluate the performance of improved varieties of crops with the existing cultivars. Each experiment was laid out in randomized complete block design with six dispersed replications. The unit plot size was varied with experiments. The result showed that improved varieties of oilseed crops mustard var. BARI Sarisha-16, soybean var. BARI Soybean-6, groundnut var. BARI Chinabadam-9, sesame var. BARI Til-4 and sunflower var. BARI Surjomukhi-2 performed better under the soil and climatic conditions of Sylhet region. This result reveled that these varieties of oilseed crops could be suitable for higher productivity and economic return.
\end{abstract}

\section{Introduction}

Bangladesh is one of the most important agrarian's countries in the world; agriculture sector is the country's main source of food security, employment, and poverty alleviation. More than 70 percent of Bangladesh's population and 77 percent of its workforce lives in rural areas. Nearly half of all of Bangladesh's workers and two-thirds in rural areas are directly employed by agriculture, and about 87 percent of rural households rely on agriculture for at least part of their income (World Bank Group, 2019; Rahman and Schmitz, 2007). The Sylhet regions are mostly under the Agroecological zone -20 (Eastern Surma Kushiyara Floodplain), and the soils of this region are strongly acidic (pH 4.5-5.5). Farmers mainly grow rice under rain fed ecosystem. The climate of this region is suitable for potato, tomato, cabbage, aroids, wheat and different pulse and oilseed crops (Nazrul, 2017; Nazrul and Shaheb, 2014; Nazrul et al., 2013; Shaheb et al., 2012; Sarker, et al., 2012; Nazrul and Shaheb, 2012; Rahman et al., 2013) in Rabi and Kharif seasons, respectively.

Generally, farmers in this region cultivate different crops of local varieties in both seasons under poor management practices. As a result, much lower yield is achieved in Sylhet areas (Nazrul et al., 2017; Nazrul et al., 2013). So, introduction of new crops with modern varieties along with appropriate agronomic management practices would boost up the farm productivity that will reduce the poverty level of resource poor farmers of that area. In addition, agriculture is the only economic activity of most small farmers in this region. About 40-45 \% lands of total cultivable area remain fallow due to lack of irrigation and not available suitable different crop varieties under present prevailing agro-climatic situation. Nazrul et al. (2020) reported that some crop varieties of pulse, tuber and spices performed better under the soil and climatic conditions of Sylhet region. Information related to varietal adaptability of different oilseed crops like mustard, soybean, groundnut, sesame, linseed and sunflower in the study areas of rice based rainfed eco-system under climate change situation is scanty. Hence, an 
experiment was undertaken with an objective to evaluate the yield performance of improved varieties of oil seeds crops with the existing cultivars at farmers' field of Sylhet region.

\section{Materials and Methods}

A total of six separate trials were conducted at farmer's field in Sylhet area for two consecutive crop seasons during 2017-18 and 2018-19 to evaluate the performance of improved crop varieties with the existing cultivars cultivated by the farmers. The study areas are located at Latitude $24^{\circ} 29^{\prime} \mathrm{N}$ and Longitude $91^{\circ} 39^{\prime} \mathrm{E}$ of Bangladesh. The soil of experimental plots was non-calcareous gray with low organic matter content (1.23\%), low soil $\mathrm{pH}(4.5-5.4)$, very low total $\mathrm{N}(0.06 \%)$, low content of $\mathrm{P}(9.46$ $\mu \mathrm{g} / \mathrm{g}), \mathrm{K}(0.14)$ and $\mathrm{S}(10.07)$ whereas $\mathrm{Zn}(1.13)$ and Boron (0.51) medium and optimum, respectively. Each experiment was laid out in randomized complete block design with six dispersed replications. The unit plot size was varied with the experiments.

The monthly air temperature and rainfall during the study period are presented in Figure 1 . The monthly mean minimum and maximum temperature was $9.53^{\circ} \mathrm{C}$ and $36.43^{\circ} \mathrm{C}$ during the crop season, respectively. During experimentations a total of $7684 \mathrm{~mm}$ precipitation was occurred in this region; whereas lowest rainfall $10.9 \mathrm{~mm}$ and highest $2465 \mathrm{~mm}$ was occurred in January and June, respectively.

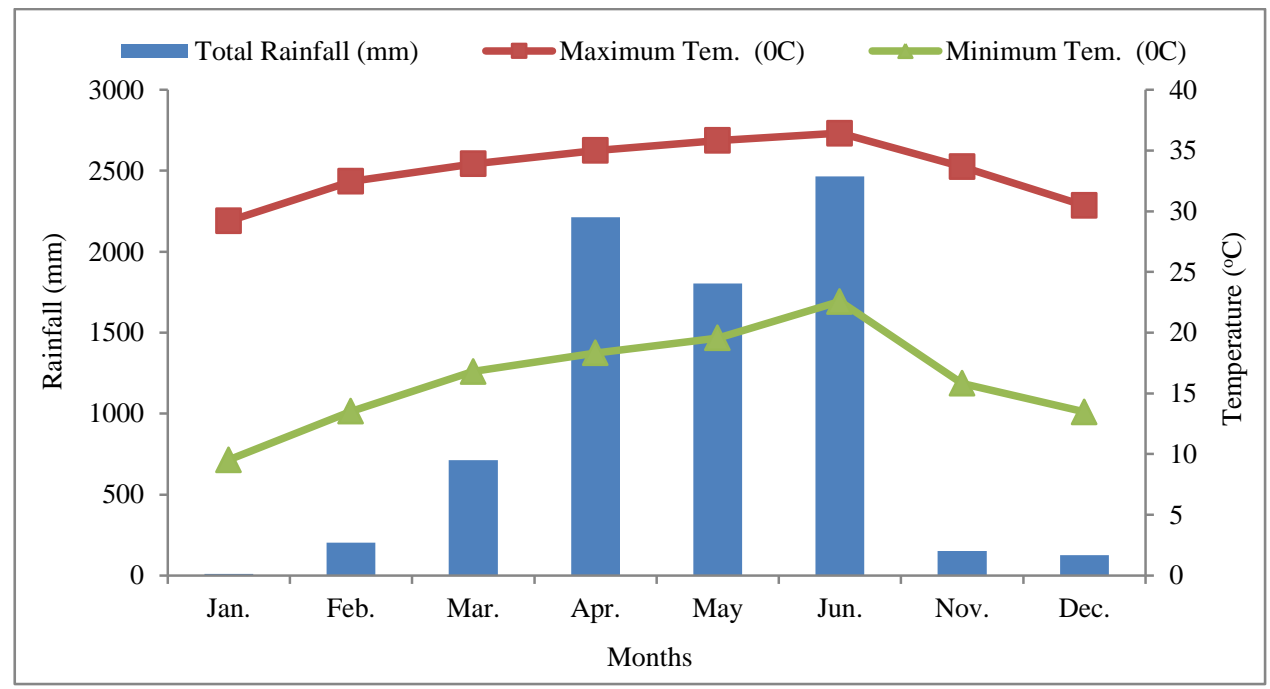

Fig. 1. Average of two years monthly maximum and minimum air temperatures $\left({ }^{0} \mathrm{C}\right)$ and total rainfall (mm) during study period (Source: Meteorological Department, Sylhet)

\section{Mustard}

The on-farm trial was conducted at farming system research and development (FSRD) site, Kamalbazar, South Surma, Sylhet. Six mustard varieties viz. BARI Sarisha-9, BARI Sarisha-11, BARI Sarisha-13, BARI Sarisha-14, BARI Sarisha-15 and BARI Sarisha-16 were used in this field trial. The crop was fertilized with 90-27-32-10-1.0-0.5 $\mathrm{kgha}^{-1}$ of NPKSZnB (FRG, 2012). Half of nitrogen and all amounts of phosphorous, potassium, sulpher, zinc and boron were applied during final land preparation. The remaining half nitrogen was applied as top dress at the time of flower initiation. The experiment was conducted under rainfed condition. The seeds were sown on 20-25 November in broadcast method in both years maintaining the seed rate of $7-8 \mathrm{~kg} \mathrm{ha}^{-1}$. The unit plot size was $12 \mathrm{~m} \times 20$ m. The crop was harvested on18-25 February in both years. Pesticides Rovral 50 WP $0.2 \%$ for controlling gray blight and Nitro 505 EC @ $0.5 \mathrm{ml} \mathrm{L}^{-1}$ of water was used against mustard aphid. 


\section{Soybean}

The experimentation was conducted at farmer's field under farming system research and development (FSRD) site, Kamalbazar, South Surma, Sylhet. Three soybean varieties viz. BARI Soybean-5, BARI Soybean-6 and Shohag were used in this experiment. Cop was fertilized with $23-30-50-15-1.0 \mathrm{~kg} \mathrm{ha}^{-1}$ of NPKSB (FRG, 2012). All fertilizer nutrients were applied during final land preparation. Seeds of soybean were sown on 15-18 December in broadcast method in both years with maintained the seed rate of $80-90 \mathrm{Kg} \mathrm{ha}^{-1}$. The unit plot size was $8 \mathrm{~m} \times 5 \mathrm{~m}$. The crop was harvested at full maturity on 5-10 April in both years. There was no remarkable disease and pest attack, except white fly and it was successfully controlled by applying Nitro $505 \mathrm{EC}$ at the rate of $0.5 \mathrm{ml} \mathrm{L}^{-1}$.

\section{Groundnut}

The experiment was conducted at farmer's field under multilocation testing (MLT) site, Sunamganj. The experimental material comprised of two varieties viz. BARI Chinabadam-8 and BARI Chinabadam-9 including local were used in this experiment. The seeds of groundnut were sown on 2-5 November in both years with maintaining the spacing of $40 \mathrm{~cm} \times 15 \mathrm{~cm}$. The unit plot size was $8 \mathrm{~m} \times 5$ $\mathrm{m}$; where total of 650 plants were accommodated and harvested on 5-7 March in both years with maintaining 90-100 kg seeds ha ${ }^{-1}$. Before sowing, seeds were treated with Provex @ $0.2 \%$ to prevent seed and soil borne diseases. Weeding followed by irrigations were done twice at 15-20 and 45-50 days after sowing of seed and earthing up was followed as per package of practices of groundnut (Pradheeban et al., 2016).The crop was fertilized with 25-160-85-300-10 kg urea-TSP-MoP-GypsumBoric acid ha ${ }^{-1}$. The half urea and entire amount of TSP, MP, gypsum and boric acid were applied during final land preparation. The rest half urea was top dressed at the initial stage of peg developments.

\section{Sesame}

The on-farm trial was conducted at upper-part of Hakaluki haor, Beanibazar area under Sylhet. Four sesame varieties viz. BARI Til-2, BARI Til-3, BARI Til-4 and T-6 was used in this trial. The unit plot size was $10 \mathrm{~m}$ x $10 \mathrm{~m}$. Seeds were sown in broadcast method. The fertilizer nutrients NPKSZnB @ 6030-40-18-2-0.5 were applied in the form of urea, TSP, MoP, Sulpher, Gypsum and Boron, respectively as per FRG 2012. Full dose of all fertilizers and half of urea were applied at the time of final land preparation. Remaining nitrogen was applied as top dress at 25-30 days after sowing. The trial was conducted under rainfed condition. Sesame seeds (7-8 $\mathrm{kg} \mathrm{ha}^{-1}$ ) were sown on 15-18 March in both years. The crop was harvested at full maturity on 12-15 June in both years. Intercultural operations viz. weeding and thinning were done in order to support normal plant growth.

\section{Linseed}

The experiment was conducted at farmer's field under multilocation testing (MLT) site, Zokiganj. Four different cultivars of linseed viz. BARI Tisi-1 (Nila), Noakhali local, Patuakhali local and Zokiganj local were tested in this field trial. The crop was fertilized with 31-13-20-8 $\mathrm{kg} \mathrm{ha}^{-1}$ of NPKS (FRG, 2012). Half of nitrogen and all phosphorous, potassium and sulpher were applied during final land preparation. The remaining nitrogen was applied at the time of flower initiation as top dress. The seeds $\left(7-8 \mathrm{~kg} \mathrm{ha}^{-1}\right)$ were sown on 20-25 November in both years in broadcast method. The unit plot size was $10 \mathrm{~m} \times 8 \mathrm{~m}$. Once weeding followed by irrigation was provided at 30-35 days after sowing. The crop was harvested at maturity on 13-15 March in both years. The fungicide Bavistin 70 WP (0.2 \%) was applied for controlling foot rot disease and in order to support normal growth of linseed. 


\section{Sunflower}

The field trial was conducted at farming system research and development (FSRD) site, Kamalbazar, South Surma, Sylhet. Three sunflower varieties viz. BARI Surjomukhi-2, BARI Surjomukhi-3 and Hysun-33 were used in this experiment. The crop was fertilized with 90-35-75-25-1.0-0.5 kg ha-1 of NPKSZnB (FRG, 2012). Half of nitrogen and all phosphorous, potassium, sulpher, zinc and boron were applied during final land preparation. The remaining nitrogen was applied as top dress in two equal splits at 20-25 and 40-45 days after sowing (DAS). The seeds (10-12 $\left.\mathrm{kg} \mathrm{ha}^{-1}\right)$ were sown on 1520 November in both years maintaining the spacing of $50 \mathrm{~cm} \times 30 \mathrm{~cm}$. The unit plot size was $8 \mathrm{~m} \times 5 \mathrm{~m}$. The crop was harvested on 25-28 February in both years. Seeds were treated with Provex-200 @ 3g kg-

${ }^{1}$ before sowing. Twice irrigations were done at 30 and 50 days after sowing of seed. The yield data was recorded from whole plot basis. Yield and yield contributing characters were analyzed statistically using "STAR" software package and means were separated by LSD test at $0.05 \%$ level of significance.

\section{Results and discussion}

\section{Mustard}

Seed yield and yield components of mustard varieties are presented in Table 1. Number of days required from sowing to harvesting (76-103 days) of mustard varieties differed significantly. The duration of BARI Sarisha-16 was the maximum (103 days) which was at par with BARI Sarisha-13 (100 days) and BARI Sarisha-11 (98 days). On the contrary, duration of BARI Sarisha-14 (84 days) and BARI Sarisha-15 (88 days) was identical but 19 days shorter than BARI Sarisha-16.The maximum plant height $(126.30 \mathrm{~cm})$ was recorded in BARI Sarisha-16 which was closely followed by BARI Sarisha-11 and lowest plant height $(80.00 \mathrm{~cm})$ was measured in BARI Sarisha-9.On the other hand, number of siliquaplant ${ }^{-1}$ was significantly different among the varieties (Table 1). The highest number of siliquae plant ${ }^{-1}$ was recorded in BARI Sarisha-11 (164) which was identical with BARI Sarisha-16 (154). Inversely, BARI Sarisha-13 (68) and BARI Sarisha-15 (66) produced statistically similar number of siliquaplant ${ }^{-1}$ but much lower than BARI Sarisha-16 (154). The lowest number of siliqua plant $^{-1}$ was observed in BARI Sarisha-9 (53). The results were in agreement with the findings of Islam et al. (2015).

Number of seeds siliqua ${ }^{-1}$ is a genetically controlled trait differed significantly in mustard varieties. BARI Sarisha-14 had the highest number of seeds siliqua ${ }^{-1}$ (26.67). BARI Sarisha-11 (11.38) and BARI Sarisha-16 (12.67) produced statistically identical number of seeds siliqua ${ }^{-1}$. The seed size i.e. 1000-seed weight of BARI Sarisha-11 (3.1 g), BARI Sarisha-13 (3.4 g) and BARI Sarisha-14 (3.7 g) was identical. BARI Sarisha- 16 produced the smaller sized seeds $(2.4 \mathrm{~g})$ which was statistically similar with BARI Sarisha-9 (2.5 g). Yield is directly proportional to the cumulative effect of yield attributes. The highest seed yield was recorded in BARI Sarisha-16 $\left(1230 \mathrm{kgha}^{-1}\right)$ which was at par with BARI Sarisha-11 $\left(1140 \mathrm{kgha}^{-1}\right)$. The higher seed yields in the afore said varieties were occurred due to higher number of siliqua plant ${ }^{-1}$ though much lower in seedssiliqua ${ }^{-1}$ and also seed size. Mian and Islam (2010) also reported higher seed yield due to higher siliqua plant ${ }^{-1}$. On the contrary, as a short duration varieties, BARI Sarisha-14 and BARI Sarisha-15 produced significantly lower seed yields of 890 and $980 \mathrm{~kg} \mathrm{ha}^{-1}$, respectively compared to long duration varieties (100-103days). The results revealed that long duration var. BARI Sarisha-11 and BARI Sarisha-16 could be grown in fallow land areas for higher yield but if other crops grown in Kharif-I then short duration mustard variety BARI Sarisha-14 and BARI Sarisha-15 could be grown. 
Table 1. Days to maturity, plant height, seed yield and yield contributing characters of mustard varieties at rainfed eco-system (Pooled)

\begin{tabular}{|c|c|c|c|c|c|c|}
\hline Name of variety & $\begin{array}{l}\text { Days to } \\
\text { maturity }\end{array}$ & $\begin{array}{l}\text { Plant height } \\
\text { (cm) }\end{array}$ & $\begin{array}{l}\text { Siliqua } \\
\text { plant }^{-1}\end{array}$ & $\begin{array}{c}\text { Seeds } \\
\text { Siliqua }^{-1}\end{array}$ & $\begin{array}{l}\text { 1000-seed } \\
\text { weight (g) }\end{array}$ & $\begin{array}{l}\text { Seed yield } \\
\left(\mathrm{kg} \mathrm{ha}^{-1}\right)\end{array}$ \\
\hline BARI Sarisha-9 & 76 & 80.00 & 53 & 13.33 & 2.5 & 680 \\
\hline BARI Sarisha-11 & 98 & 105.00 & 160 & 11.38 & 3.1 & 1140 \\
\hline BARI Sarisha-13 & 100 & 100.70 & 68 & 22.33 & 3.4 & 970 \\
\hline BARI Sarisha-14 & 84 & 85.00 & 55 & 26.67 & 3.7 & 780 \\
\hline BARI Sarisha-15 & 88 & 87.00 & 66 & 22.67 & 3.2 & 780 \\
\hline BARI Sarisha-16 & 103 & 126.30 & 154 & 12.67 & 2.4 & 1230 \\
\hline $\mathrm{LSD}_{(0.05)}$ & 5.54 & 14.69 & 5.3 & 5.29 & 0.2 & 0.18 \\
\hline $\mathrm{CV}(\%)$ & 3.30 & 8.44 & 7.5 & 16.10 & 5.1 & 10.95 \\
\hline
\end{tabular}

\section{Soybean}

Plant height, number of pods plant ${ }^{-1}$, seeds pod $^{-1}, 100$-seed weight and seed yield of soybean varieties are presented in Table 2 . The tallest plant $(54.80 \mathrm{~cm})$ was obtained by BARI Soybean-6. Pods plant ${ }^{-1}$ and seeds $\operatorname{pod}^{-1}$ of different soybean varieties did not differ significantly due to uniformity of pods plant $^{-1}$ and seeds pod ${ }^{-1}$. BARI Soybean-6 produced numerically maximum number of pods, as a result, the highest number of pods plant (31.10) was recorded in this variety and it was statistically identical with others. Higher number of seeds pod $^{-1}$ was also observed in BARI Soybean-6. The weight of 100seed of soybean varieties varied significantly in rain fed eco-system under climate change situation. Hundred seeds weight followed a similar trend to seeds pod $^{-1}$. The highest weight $(12.41 \mathrm{~g})$ of 100-seed was recorded in BARI Soybean-6. Seed yield was not varied significantly but numerically BARI Soybean-6 produced higher seed yield $\left(1365 \mathrm{~kg} \mathrm{ha}^{-1}\right)$ while Sohag was the lowest yielder $\left(1184 \mathrm{~kg} \mathrm{ha}^{-}\right.$ ${ }^{1}$ ). Yield variation in different soybean varieties was attributed to the cumulative effects of different yield components. Similar finding was also reported by Islam et al. (2015) and Islam and Biswas (2010).

Table 2. Yield contributing characters and yield of soybean varieties at farmer's field of Sylhet (Pooled )

\begin{tabular}{l|c|c|c|c|c|c}
\hline \multicolumn{1}{c|}{ Variety } & $\begin{array}{c}\text { Plant height } \\
(\mathbf{c m})\end{array}$ & Pods plant $^{\mathbf{- 1}}$ & $\begin{array}{c}\text { Seeds } \\
\text { pod }^{-1}\end{array}$ & $\begin{array}{c}\text { 100-seed } \\
\text { weight (g) }\end{array}$ & $\begin{array}{c}\text { Days to } \\
\text { maturity }^{-}\end{array}$ & $\begin{array}{c}\text { Seed yield } \\
\left.\text { (kg ha }^{-\mathbf{1}}\right)\end{array}$ \\
\hline BARI Soybean-5 & 51.90 & 30.76 & 2.45 & 10.83 & 112 & 1285 \\
BARI Soybean-6 & 54.80 & 31.10 & 2.60 & 12.41 & 113 & 1365 \\
Sohag & 50.58 & 29.70 & 2.30 & 10.10 & 112 & 1184 \\
\hline LSD $_{(0.05 \%)}$ & 2.36 & NS & NS & 1.96 & NS & NS \\
CV $(\%)$ & 2.60 & 7.48 & 6.80 & 10.07 & 6.24 & 7.93 \\
\hline
\end{tabular}

\section{Groundnut}

The maximum days to maturity was recorded in BARI Chinabadam-9 followed by BARI Chinabadam8 (Table 3). The maximum number of pods plant $^{-1}$ (16.87) was recorded in BARI Chinabadam-9 followed by BARI Chinabadam-8, while the lowest in local cultivar (14.83). The highest 100-kernel weight (39.65 g) was recorded in BARI Chinabadam-9 and the lowest (33.92 g) was in local. Higher kernel yield contributed to greater shelling percent and provide higher nut yield. The maximum shelling percent $(76.64 \%)$ of groundnut was recorded in BARI Chinabadam-9 followed by BARI Chnabadam- 8 and local. The yield did not varied significantly but numerically higher nut yield $(1.57 \mathrm{t}$ $\mathrm{ha}^{-1}$ ) was recorded in BARI Chinabadam-9 followed by BARI Chinabadam-8 $\left(1.40 \mathrm{t} \mathrm{ha}^{-1}\right)$ and the lowest in local $\left(1.25 \mathrm{t} \mathrm{ha}^{-1}\right)$. Among the yield components, number of pods plant ${ }^{-1}$ and kernel weight were more closely associated with pod yield $\mathrm{ha}^{-1}$. 
Table 3. Days to maturity, yield contributing characters and nut yield of different groundnut varieties at farmer'sfield in Sylhet region (Pooled).

\begin{tabular}{|c|c|c|c|c|c|}
\hline Variety & $\begin{array}{c}\text { Days to } \\
\text { maturity }\end{array}$ & $\begin{array}{c}\text { Pods plant }^{-1} \\
\text { (no.) }\end{array}$ & $\begin{array}{c}\text { 100-kemel wt. } \\
(\mathrm{g})\end{array}$ & $\begin{array}{c}\text { Shelling } \\
(\%)\end{array}$ & $\begin{array}{c}\text { Nut yield } \\
\left(\mathrm{t} \mathrm{ha}^{-1}\right)\end{array}$ \\
\hline BARI Chinbadam-8 & 139 & 15.67 & 34.81 & 73.14 & 1.40 \\
\hline BARI Chinbadam-9 & 142 & 16.87 & 39.65 & 76.64 & 1.57 \\
\hline Local & 137 & 14.83 & 33.92 & 69.78 & 1.25 \\
\hline $\operatorname{LSD}(0.05)$ & NS & NS & NS & NS & NS \\
\hline $\mathrm{CV}(\%)$ & 1.37 & 9.55 & 7.60 & 3.43 & 13.28 \\
\hline
\end{tabular}

\section{Sesame}

Results indicated that the maximum plant height $(101.10 \mathrm{~cm})$ was found in the variety BARI Til-4 that was followed by T-6 and BARI Til-2 $(99.89 \mathrm{~cm})$. The maximum number of pods plant ${ }^{-1}$ was recorded in var. BARI Til-2 (71.33) that was followed by T-6 and BARI Til-4. Higher number of seeds pod ${ }^{-1}$ was found in var.T-6 (70.33) followed by BARI Til-2 (67.33) and the lowest seeds pod ${ }^{-1}$ in BARI Til-3 (53.00). The maximum pod length $(2.90 \mathrm{~cm})$ was found in T-6 followed by BARI Til-2. The maximum seed yield was recorded in BARI Til-4 $\left(1.15 \mathrm{tha}^{-1}\right)$ that was statistically similar to that of BARI Til-2 $\left(1.14 \mathrm{tha}^{-1}\right)$, whereas lowest seed yield was produced by the variety BARI Til-3 $\left(0.84 \mathrm{t} \mathrm{ha}^{-1}\right)$.

Table 4. Seed yield and yield contributing characters of sesame varieties at farmer's field of Sylhet (Pooled)

\begin{tabular}{|c|c|c|c|c|c|c|}
\hline Variety & $\begin{array}{l}\text { Plant height } \\
\text { (cm) }\end{array}$ & $\begin{array}{c}\text { Plant } \mathbf{m}^{-2} \\
\text { (nos.) }\end{array}$ & $\begin{array}{c}\text { Pods plant }^{-1} \\
\text { (nos.) }\end{array}$ & $\begin{array}{c}\text { Seeds pod }^{-1} \\
\text { (nos.) }\end{array}$ & $\begin{array}{l}\text { Pod length } \\
\text { (cm) }\end{array}$ & $\begin{array}{c}\text { Seed yield } \\
\left(\mathrm{t} \mathrm{ha}^{-1}\right)\end{array}$ \\
\hline BARI Til-2 & 99.89 & 37.23 & 71.33 & 67.33 & 2.67 & 1.14 \\
\hline BARI Til-3 & 95.76 & 44.57 & 50.33 & 53.00 & 2.37 & 0.84 \\
\hline BARI Til-4 & 101.10 & 40.57 & 65.33 & 61.33 & 2.60 & 1.15 \\
\hline T-6 (Control) & 99.83 & 41.23 & 68.67 & 70.33 & 2.90 & 0.98 \\
\hline$\overline{\operatorname{LSD}(0.05)}$ & 2.57 & NS & 10.21 & 11.69 & 0.19 & 0.18 \\
\hline CV $(\%)$ & 1.25 & 9.61 & 8.33 & 8.92 & 1.84 & 8.14 \\
\hline
\end{tabular}

\section{Linseed}

The highest plant height was obtained in BARI Tisi-1 $(64.85 \mathrm{~cm})$ while the shortest plant in Noakhalilocal $(52.73 \mathrm{~cm})$. The highest number of pods plant ${ }^{-1}$ was recorded in Zakigonj-local (31.40). But plants $\mathrm{m}^{-2}$ and seeds pod ${ }^{-1}$ was non-significant (Table 5). Among the varieties, Zakigonj-local produced highest 1000 seeds weight $(4.01 \mathrm{~g})$ that was followed by Noakhali local $(3.66 \mathrm{~g})$ and the lowest 1000 seeds weight in BARI Tisi-1 (3.57 g). Likewise, the highest seed yield $\left(0.94 \mathrm{t} \mathrm{ha}^{-1}\right)$ of linseed was recorded in Zakigonj-local that was statistically followed by Noakhali-local $\left(0.81 \mathrm{t} \mathrm{ha}^{-1}\right)$. However, the lowest seed yield $\left(0.74 \mathrm{t} \mathrm{ha}^{-1}\right)$ was found in Patuakhali-local.

Table 5. Seed yield and yield contributing characters of linseed at farmer's field of Sylhet region (Pooled)

\begin{tabular}{|c|c|c|c|c|c|c|}
\hline Variety & $\begin{array}{c}\text { Plant height } \\
\text { (cm) }\end{array}$ & $\begin{array}{c}\text { Pods plant }^{-1} \\
\text { (nos.) }\end{array}$ & $\begin{array}{l}\text { Plants } \mathrm{m}^{-2} \\
(\mathrm{~cm})\end{array}$ & $\begin{array}{c}\text { Seeds pod }^{-1} \\
\text { (nos.) }\end{array}$ & $\begin{array}{l}\text { 1000- seed } \\
\text { weight }(\mathrm{g})\end{array}$ & $\begin{array}{c}\text { Seed yield } \\
\left(\mathrm{t} \mathrm{ha}^{-1}\right)\end{array}$ \\
\hline Nila (BARI Tisi-1) & 64.85 & 21.28 & 221 & 7.22 & 3.57 & 0.76 \\
\hline Noakhali-local & 49.55 & 20.63 & 191 & 7.37 & 3.66 & 0.81 \\
\hline Patuakhali-local & 52.73 & 19.13 & 207 & 7.53 & 3.64 & 0.74 \\
\hline Zakigonj-local & 50.80 & 31.40 & 201 & 7.73 & 4.01 & 0.94 \\
\hline LSD (0.05) & 4.17 & 9.6 & NS & NS & 0.6 & 0.27 \\
\hline $\mathrm{CV}(\%)$ & 3.69 & 20.55 & 8.21 & 7.53 & 4.74 & 5.93 \\
\hline
\end{tabular}




\section{Sunflower}

The var. BARI Surjomukhi-2 produced the maximum $(167.77 \mathrm{~cm})$ plant height, which was lowest value $(91.02 \mathrm{~cm})$ produced by BARI Surjomukhi-3 at physiological maturity (Table 6). The plant heights of sunflower var. BARI Surjomukhi-2 was uneven but means height was statistically than others. The differences in plant height may be attributed to the genetic potential of variety and the other prevailing environmental conditions. The plant height of some sunflower hybrids increased with increasing temperature. Similar results were reported by Anderson et al. (1978); Qadir (2006) and Canava et al. (2010). The maximum days to maturity (126) were recorded in hybrid Hysun-33 and minimum days to maturity were observed in BARI Surjomukhi-3 (102).

Total seeds head ${ }^{-1}$ (903.15) was highest in BARI Surjomukhi-2 and that of minimum (757.48) was produced in BARI Sunflower-2. This may be due to comparatively large head size and small seed size. Similar trend was also found in case of seed weight head ${ }^{-1}$. Maximum seed weight $(51.42 \mathrm{~g})$ head $^{-1}$ as obtained from BARI Surjomukhi-2 followed by hybrid Hysun-33 and BARI Surjomukhi-3. The 1000seed of the sunflower cultivars ranged from 61.38 to $95.00 \mathrm{~g}$. The sunflower var. BARI Surjomukhi-2 produced the maximum 1000 -seed weight $(95.00 \mathrm{~g})$, which was significantly different from the other values of this trait. BARI Surjomukhi-3 produced the minimum 1000 -seed weight $(61.38 \mathrm{~g})$ in Table 4 . Similar 1000-seed weight was reported by Hossain et al. (2018). The seed yield of tested sunflower varieties did not differ significantly. The seed yield plant $^{-1}$ of all the sunflower cultivars ranged from 1783 to $2033 \mathrm{~kg} \mathrm{ha}^{-1}$. Though seed yield was not significant but maximum seed yield $\left(2033 \mathrm{~kg} \mathrm{ha}^{-1}\right)$ was observed in BARI Surjomukhi-2.The lowest seed yield $\left(1783 \mathrm{~kg} \mathrm{ha}^{-1}\right)$ was found in the BARI Surjomukhi-3.

Table 6. Seed yield and yield contributing characters of sunflower varieties at farmer's field of Sylhet region (Pooled)

\begin{tabular}{l|c|c|c|c|c|c}
\hline \multicolumn{1}{c|}{ Variety } & $\begin{array}{c}\text { Plant height } \\
(\mathbf{c m})\end{array}$ & $\begin{array}{c}\text { Days to } \\
\text { maturity }\end{array}$ & $\begin{array}{c}\text { Total seed } \\
\text { head }^{-1}\end{array}$ & $\begin{array}{c}\text { Seed weight } \\
\text { head }^{-1}(\mathbf{g})\end{array}$ & $\begin{array}{c}\text { 1000- seed } \\
\text { weight }(\mathbf{g})\end{array}$ & $\begin{array}{c}\text { Seed yield } \\
\left(\mathbf{k g ~ h a}^{-1}\right)\end{array}$ \\
\hline BARI Surjomukhi-2 & 167.77 & 105 & 903.15 & 51.42 & 61.38 & 2033 \\
BARI Surjomukhi-3 & 91.02 & 102 & 757.48 & 42.79 & 65.00 & 1783 \\
Hysun-33 & 138.00 & 126 & 793.87 & 43.14 & 95.00 & 1800 \\
\hline LSD $_{(0.05 \%)}$ & 6.65 & 2.77 & 2.78 & 2.77 & 2.78 & $\mathrm{NS}$ \\
CV $(\%)$ & 3.25 & 5.37 & 2.57 & 2.60 & 5.53 & 11.37 \\
\hline
\end{tabular}

\section{Conclusion}

It showed from the results that mustard var. BARI Sarisha-16, soybean var. BARI Soybean-6; groundnut var. BARI Chinabadam-9; sesame var. BARI Til-4 and sunflower var. BARI Surjomukhi-3 could be grown in Sylhet region under AEZ 20 for higher productivity and economic return.

\section{Acknowledgement}

Authors are gratefully acknowledged Bangladesh Agricultural Research Institute, Gazipur and Meteorological Department, Sylhet for providing financial help and logistic support and weather data, respectively. Thanks to others who contributed in editing and compiling the manuscript. 


\section{References}

Anderson, W.K., R.C.G. Smith and J.R. Mc William. 1978. A Systems approach to the adaptation of sunflower to new environments I. Phenology and development. Field Crops Res. 1: 141-152.

Canavar, Ö., F. Ellmer and F.M. Chmielewski. 2010. Investigation of yield and yield components of sunflower (Helianthus annuus L.) cultivars in the ecological conditions of Berlin (Germany). HELIA, 33, Nr. 53, pp.117-130.

Gulles, A.A., V.I. Bartolome, R.I.Z.A. Morantte, L.A. Nora, C.E.N. Relente, D.T. Talay and G. Ye. 2014. Randomization and analysis of data using STAR [Statistical Tool for Agricultural Research]. Philippine J. Crop Sci. 39 (supplement 1): 137.

Hossain, M.K., M.M. Islam, A.A. Mamun and S.M. Abdullah and Al. Mamun. 2018. Performance of sunflower genotypes in non-saline and saline soils of southern Bangladesh. Agron. J. 21(1): 1-7.

Islam, M.N, M.S. Rahman, M.S. Alom and M. Akhteruzzaman. 2015. Performance of different crops productivity enhancement through adaptation of crop varieties at char land in Bangladesh. Bangladesh J. Agril. Res. 40(4): 629-640.

Islam, M.N. and M. Biswas. 2010. Performance of soybean varieties in the char land area. Annual Res. Report. Agronomy Division, Bangladesh Agril. Res. Institute, Gazipur-1701. pp.97-98.

Islam, M.N., M. Akhteruzzamam and S. Rahman. 2010. Performance of lentil varieties in char land areas. Annual Res. Report. Agronomy Division, Bangladesh Agril. Res. Institute, Gazipur-1701. pp.7677.

Mian, M.A.K. and M.R. Islam. 2010. Adaptation of BARI released crop varieties in char land. Annual Res. Report. Agronomy Division, Bangladesh Agril. Res. Institute, Gazipur-1701. pp.93-94.

Nazrul, M.I. 2017. On-farm verification of linseed and sesame variety for Fallow-Fallow-T. Aman rice cropping system in Sylhet region of Bangladesh. Bangladesh Agron. J. 20(1): 7-12.

Nazrul, M.I. and M.R. Shaheb. 2012. Screening of pulse crops for fallow land utilization in Sylhet region. Bangladesh Agron. J. 15(2): 59-65.

Nazrul, M.I. and M.R. Shaheb. 2014. Performance of sweet gourd as relay with transplanted aman rice under rainfed ecosystem in Sylhet region. Bangladesh Agron. J. 17(2): 47-53.

Nazrul, M.I., M.K. Hasan and M.R.I. Mondal. 2017. Production potential and economics of mung bean in rice based cropping pattern in Sylhet region under AEZ 20. Bangladesh J. Agril. Res. 42(3): 413424.

Nazrul, M.I., M.R Shaheb, M.A.H. Khan and A.S.M.M.R. Khan. 2013. On-Farm Evaluation of Production Potential and Economic Returns of Potato-Rice Based Improved Cropping System. Bangladesh Agron. J. 16(2): 41-50.

Nazrul, M.I., S.T. Zannat and M.A. Ali. 2020. Evaluation on the field performance of different crops grown under acidic soil in Sylhet region of Bangladesh. Int. J. Sustain. Crop Prod. 15(1): 7-12.

Qadir, G. 2006. Morpho-genetic expression of sunflower under varied temperature and moisture regimes. Ph.D. Thesis, University of Arid Agriculture, Rawalpindi, Pakistan.

Rahman, K.M.M. and P.M. Schmitz. 2007. Food Production Sustainability and Security in Bangladesh. Bangladesh Agricultural University, Mymensingh and Justus-Liebig-University, Giessen, Germany.

Rahman, M.A., N.C.D. Barma, M.H. Sarker, M.M.R. Sarker and M.I. Nazrul. 2013. Adaptability of wheat varieties in strongly acidic soils of Sylhet. Banagladesh J. Agril. Res. 38(1): 97-104.

Rakulan, G., L. Pradheeban, K. Nishanthanand and S. Sivachandiran. 2016. Effect of different height of earthing up on yield performance of groundnut under irrigated condition in kilinochchi district, Sri Lanka. World J. Pharm. Life Sci. 2(4): 471-481.

Shaheb, M.R., M.I. Nazrul and M. Ali. 2012. Performance of mustard varieties for fallow land utilization in Sylhet region. Bangladesh Agron. J. 15(2): 47-52. 
World Bank Group. 2019. Bangladesh Climate-Smart Agriculture Investment Plan: Investment Opportunities in the Agriculture Sector's Transition to a Climate Resilient Growth Path. World Bank, Washington, DC. (C) World Bank. Https://openknowledge.worldbank.org/ handle/10986/32742 License: CC BY 3.0 IGO. 